\title{
BDX-613-515 (lev.)
}

\section{MASTER}

EFFECT OF SODIUM HYDROXIDE

ON ALUMINUM FOIL THICḰNESS

PDO 6984694, Topical Report

G. W. Bengtson, Project Leader

Project Team:

L. H. Bergthold

J. W. Chesney

J. R. Lembke

C. S. Sterrett

Published October, 1971

Prepared for the United States Atomic Energy Commission

Under Contract Number AT(29-1)-613 USAEC 


\section{DISCLAIMER}

This report was prepared as an account of work sponsored by an agency of the United States Government. Neither the United States Government nor any agency Thereof, nor any of their employees, makes any warranty, express or implied, or assumes any legal liability or responsibility for the accuracy, completeness, or usefulness of any information, apparatus, product, or process disclosed, or represents that its use would not infringe privately owned rights. Reference herein to any specific commercial product, process, or service by trade name, trademark, manufacturer, or otherwise does not necessarily constitute or imply its endorsement, recommendation, or favoring by the United States Government or any agency thereof. The views and opinions of authors expressed herein do not necessarily state or reflect those of the United States Government or any agency thereof. 


\section{DISCLAIMER}

Portions of this document may be illegible in electronic image products. Images are produced from the best available original document. 
EFFECT OF

SODIUM HYDRÖXIDE

ON ALUMINUM

FOIL THICKNESS

BDX-613-515 (Rev.)

October, 1971

Project Leader:

G. W. Bengtson

Department 812

Project Team:

L. H. Bergthold

J. W. Chesney.

J. R. Lembke

C. S. Sterrett

PDO 6984694

Topical Report 


\section{THIS PAGE}

\section{WAS INTENTIONALLY LEFT BLANK}


This report was

Prepared by:

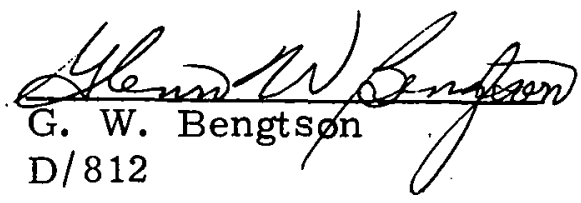

Approved by:

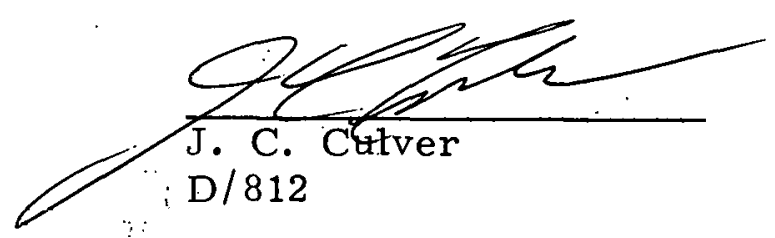

THE BENDIX CORPORATION

KANSAS CITY DIVISION

KANSAS CITY, MISSOURI

A prime contractor for the Atomic Energy Commission

Contract Number AT(29-1)-613 USAEC

This report was prepared as an account of work sponsored by the United States Government. Neither the United States nor the United States Atomic Energy Commission, nor any of their employees, nor any of their contractors, subcontractors, or their employees, makes any warranty, express or implied, or assumes any legal liability or responsibility for the accuracy, completeness or usefulness of any information, apparatus, product or process disclosed, or represents that its use would not infringe privately owned rights. 


\section{THIS PAGE}

\section{WAS INTENTIONALLY LEFT BLANK}


A study was performed to evaluate the effect on aluminum foil thickness of a surface preparation etch with a sodium hydroxide solution. It was determined that a 20 -second etch in a 20 -gram-per-liter sodium hydroxide solution reduced a 0.00045 -inch-thick aluminum foil by less than one percent. 
THIS PAGE

\section{WAS INTENTIONALLY LEFT BLANK}


CONTENTS

Section

Page

SUMMARY . . . . . . . . . . . . . . . . . • • . •

DISCUSSION . . . . . . . . . . . . . . . . . .

SCOPE AND PURPOSE . . . . . . . . . . . . . . . . . 13

PRIOR WORK . . . . . . . . . . . . . . . . . . . 13

ACTIVITY • . . . . . . . . . . . . . . . . . 13

Introduction . . . . . . . . . . . . . . . . 13

Experimental Procedure .. . . . . . . . . . . . . 14

Thickness Calculations .. . . . . . . . . . . . . 14

ACCOMPLISHMENTS . . . . . . . . . . . . . . . 18

FUTURE WORK . . . . . . . . . . . . . . . . . . . . 21

APPENDICES

A. DATA ANALYSIS FOR TEST PATTERN RESISTANCE VERSUS ETCH TIME . . . . . . . . . . . . . A-1

B. COMPUTER PROGRAM AND OUTPUT TO PREDICT THINNING OF ALUMINUM FOIL, ASSUMING CONSTANT ETCH RATE . . . . . . ....... B-1 
THIS PAGE

\section{WAS INTENTIONALLY \\ LEFT BLANK}




\section{ILLUSTRATIONS}

Figure

Page

1 Typical Etch I_ine Quality With No NaOH Surface

Preparation (Polaroid) • • • . • . . . . . • •

2 Typical Etch Line Quality With 30-Second Immersion in 20 Grams per Liter NaOH Surface Preparation (Polaroid) • • • • • • • • • • • • • • • 15

3

Foil Thickness Test Pattern, PS 6984383-9. • • • • •

4 Test Fixture, PS 44229-4(P-70200) $\because$. . . . . .

5 Resistance Versus Etch Time for Test Pattern Etched in 20 Grams per Liter $\mathrm{NaOH}$ Solution. . . . . . .

6

Calculated Thickness Versus Etch Time of Test

Pattern . . . . . . . . . . . . . . . . •

\section{TABLE}

Number

A-1 Analysis of Data for Resistance of Test Pattern Versus Etch Time in 20 Grams per Liter $\mathrm{NaOH}$ Solution... . . . . . . . . . . . . A A -3 
THIS PAGE

\section{WAS INTENTIONALLY LEFT BLANK}


This report covers investigations made from December 1970 through January 1971 to establish the amount of reduction in thickness of 1145 alloy aluminum foil as a result of the etching action of a 20 grams per liter sodium hydroxide solution. The samples studied were made from nominally 0. 00045-inch-thick 1145-0 alloy aluminum foil bonded on 0.002-inch-thick polyester film.

The results of this test indicate that there is approximately a three percent decrease in thickness for a 120-second etch, and less than one percent decrease for a 30-second etch.

It was concluded that this process is usable as a surface preparation for etching precision elements. 
THIS PAGE

\section{WAS INTENTIONALLY LEFT BLANK}




\section{DISCUSSION}

\section{SCOPE AND PURPOSE}

Evaluation of several potential techniques to obtain a matte type surface on specular finish aluminum foil prior to application of photoresist material resulted in the selection of a caustic rinse $(20$ grams per liter sodium hydroxide ( $\mathrm{NaOH})$ solution with 30 second immersion). This technique results in a finished panel etch quality within established requirements. The amount of aluminum the caustic solution removed from the exposed surface was not known, and this study was established to determine the amount of material removed.

\section{PRIOR WORK}

Techniques were recently established on a recent process development order which provided Bendix with a reliable method of measuring aluminum foil thickness on plastic substrates.

No prior work has been done at Bendix to study the effect of $\mathrm{NaOH}$ on the thickness of thin aluminum conductors.

\section{ACTIVITY}

\section{Introduction}

Bendix has a requirement to fabricate precision elements from a nominally 0.00045-inch-thick 1145-0 alloy aluminum bonded to a substrate of $0.002-$ inch polyester film. The material used was purchased according to Bendix Specification PS 43726-100-A, "Tentative Specification for Aluminum/Mylar/ Mylar/Aluminum Laminate," which allows the vendor to apply the aluminum, 
matte or specular finish, to the substrate. This degree of freedom is allowed so that the better surface for bonding can be selected to permit meeting the bond strength requirement defined in the specification. Normally the material purchased to this specification is received with the matte surface exposed; however, the lot of material for this order had the specular finish side exposed. These panels required approximately twice as much time in the etch solution and the resultant line definition was significantly poorer (Figures 1 and 2).

Several techniques to obtain a matte surface prior to application of photoresist material were evaluated. A caustic rinse $(20$ grams per liter $\mathrm{NaOH}$ solution with 30 seconds immersion) resulted in a finished panel etch quality which was within the requirements. What was not known was how much the aluminum foil was thinned as a result of the $\mathrm{NaOH}$ etching.

Experimental Procedure

Using material mentioned previously, a 6 - by 6 -inch panel with two patterns (Figure 3) was cleaned, exposed and etched in the usual manner.

Both patterns were measured for resistance to establish the original thickness. The measurements were repeated ten times each to establish the repeatability of the measuring package (Cimron digital milliohm system and the resistance fixture). All subsequent measurements were repeated ten times, with the largest error of repeatability (sigma/mean) being 0.07 percent; five of the 20 repetitions were 0.00 percent.

One pattern was immersed in a 20 grams per liter NaOH solution for 30 seconds, then in intervals of 15 seconds up to 120 seconds accumulated time, and then immersed for an additional 4 minutes. After each interval, both patterns were given a cold-tap-water rinse, an alcohol ringe and air dry with large drops blotted with a Kimwipe. After each drying, measurements were taken. Thus, one pattern was used as a control sample.

Upon completion of the 6 minute accumulated immersion time, the roles of the test patterns were reversed and the original pattern was immersed in the $\mathrm{NaOH}$ solution for 120 seconds, washed and dried, and then measured.

\section{Thlekness Calculations}

Using the test patterns mentioned before, a resistance measurement. was taken using a multi-probe system (Figure 4). A constant current was put through the circuit using the two outboard leads and the voltage drop was measured using the inboard leads. The Cimron then displays a resistance.

Text continued on page 18. 


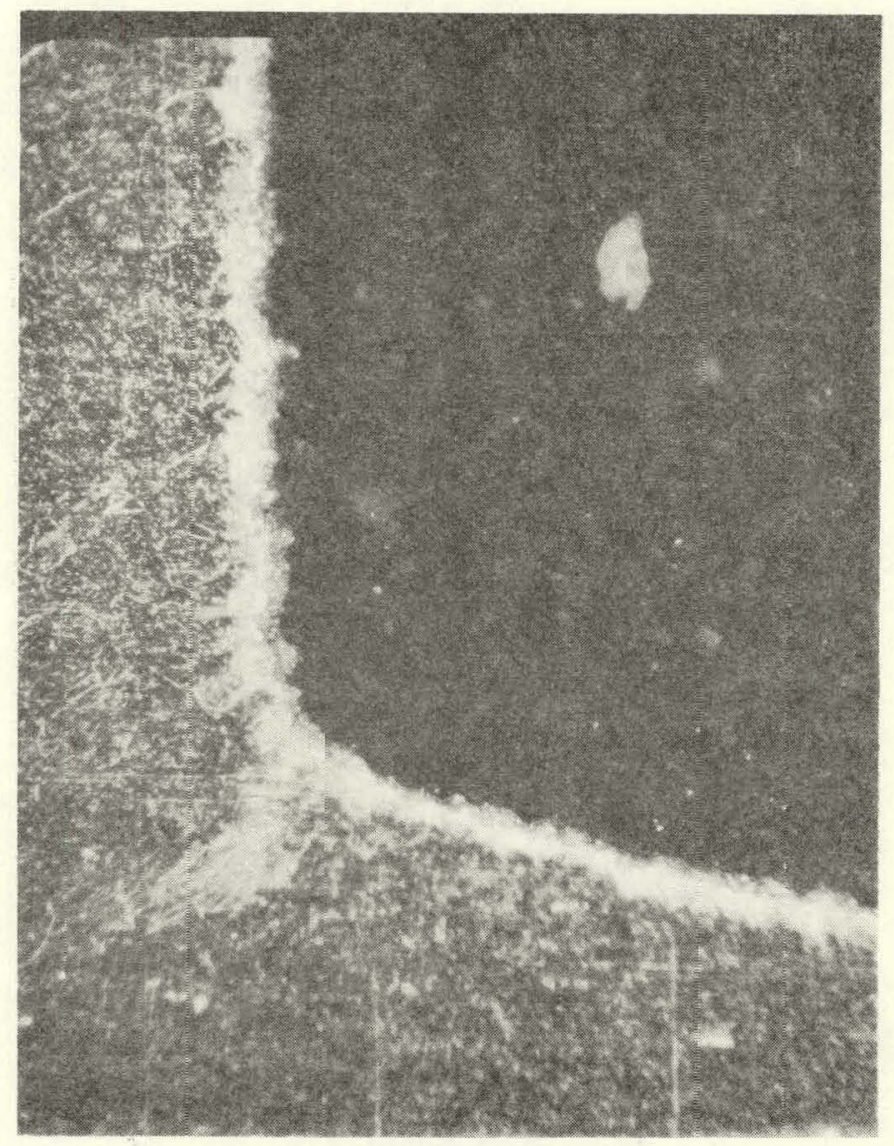

Figure 1. Typical Etch Line Quality With No $\mathrm{NaOH}$ Surface Preparation (172X) (Average 4.3 minutes required to etch. )

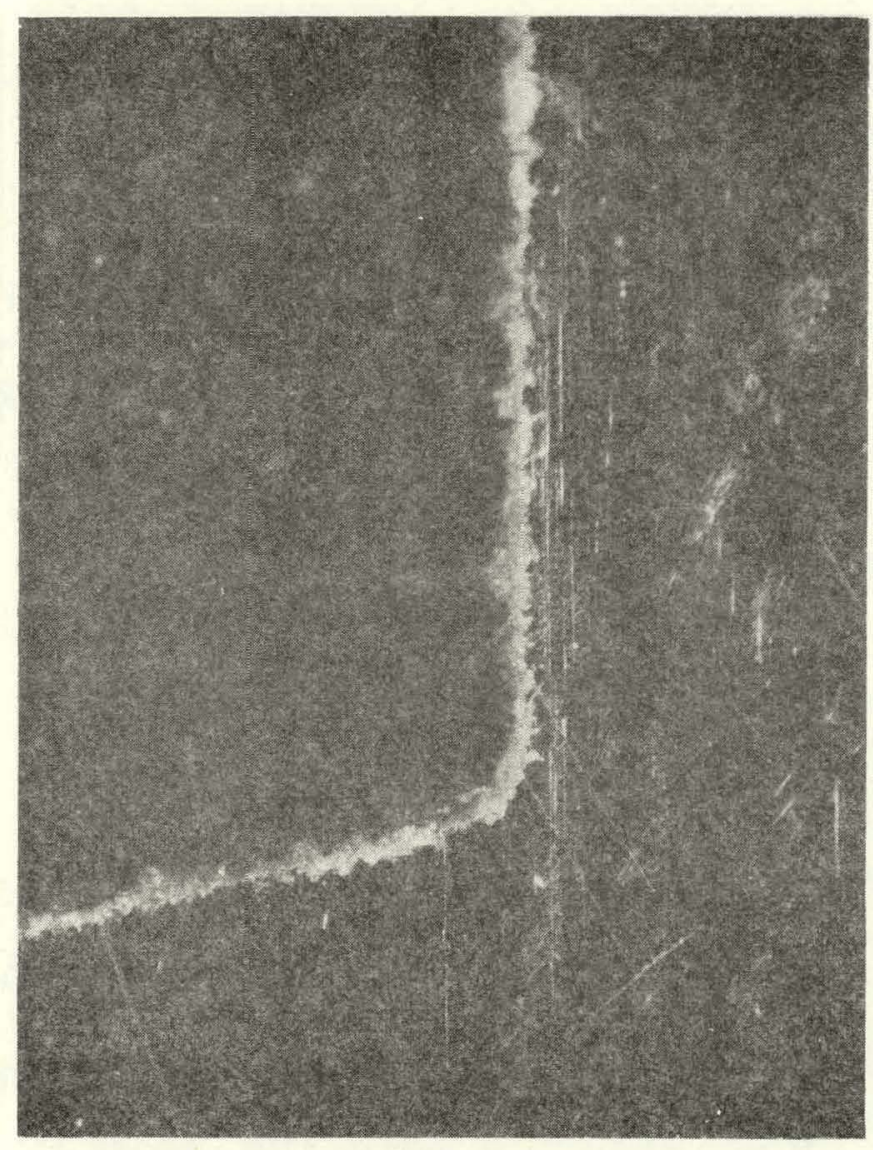

Figure 2. Typical Etch Line Quality With 30 -Second Immersion in 20 Grams per Liter $\mathrm{NaOH}$ Surface Preparation (172X) (Average 2. 4 minutes required to etch.) 


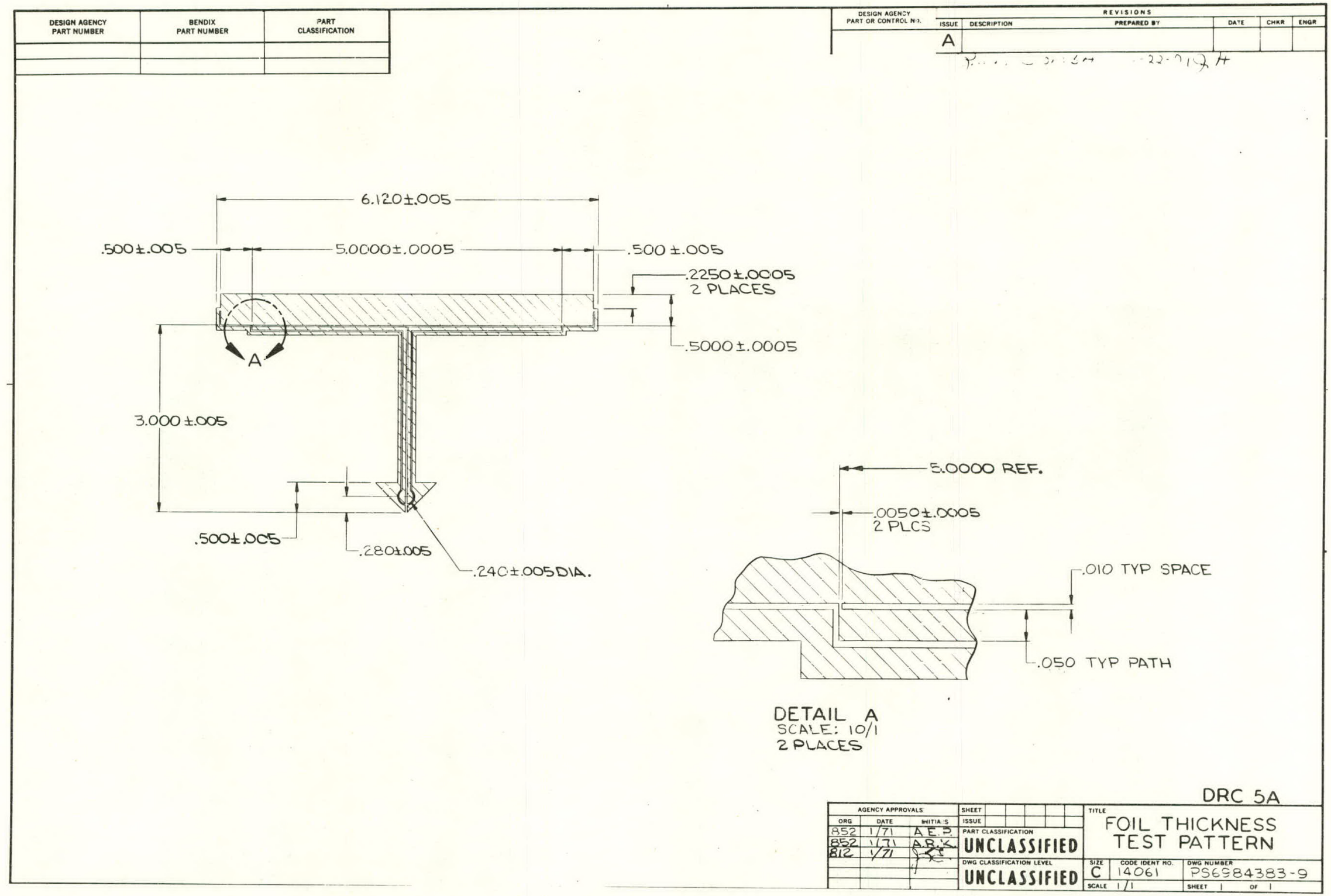

Figure 3. Foil Thickness Test Pattern, PS 6984383-9 


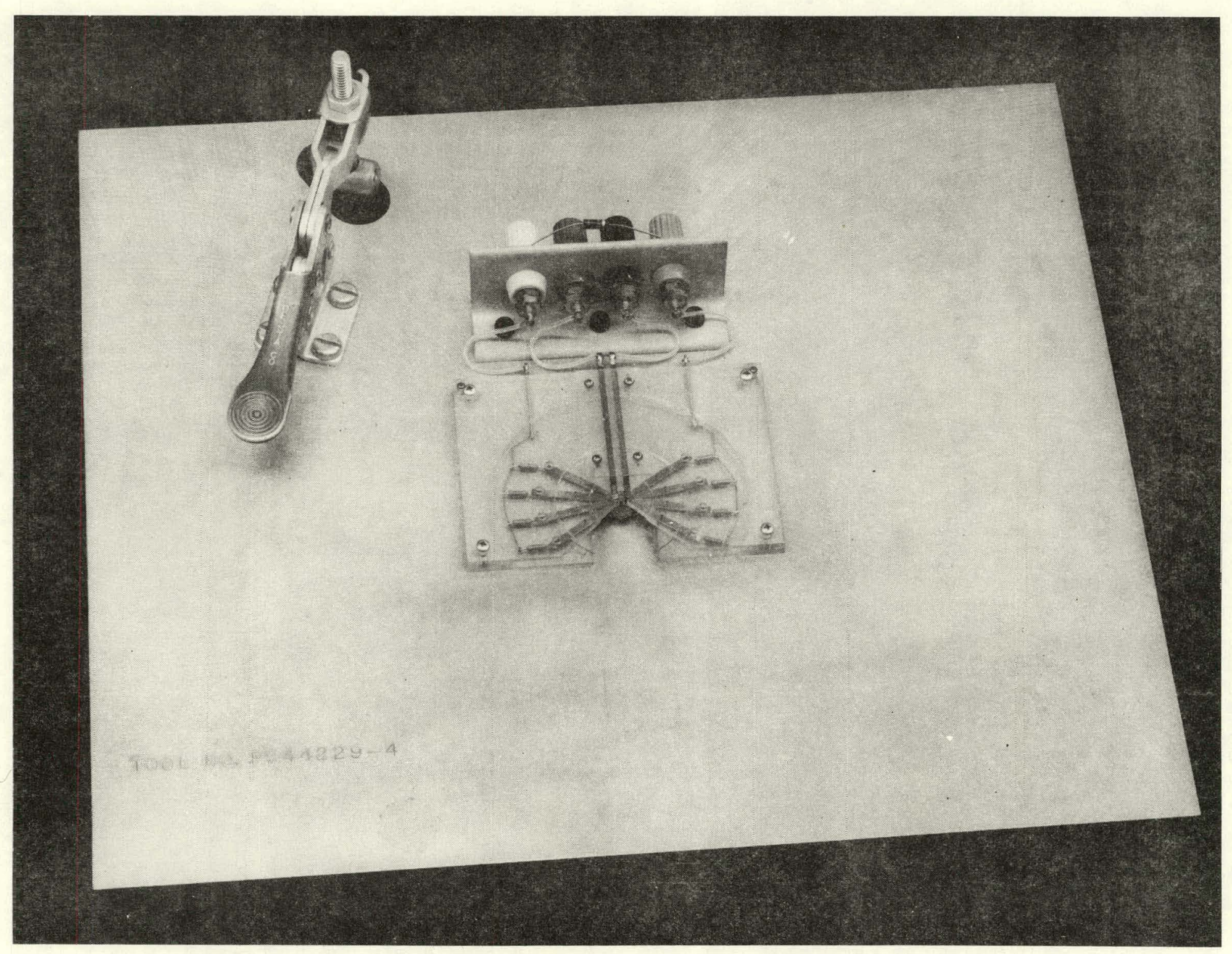

Figure 4. Test Fixture, PS 44229-4 
Using this resistance from the Cimron and the following equation

$\mathrm{R}=(\boldsymbol{\rho} / \mathrm{t}) *(\mathrm{~L} / \mathrm{W})$

where $\quad \rho=$ volume resistivity

$t=$ foil thickness

$\mathrm{L}=$ length

$\mathrm{W}=$ width

assuming that

$\mathrm{L} / \mathrm{W}=10$

and that this ratio did not change significantly with exposure to the $\mathrm{NaOH}$. Note length is the distance between voltage leads, and width is the distance $0.500 \pm 0.0005$ called out on the drawing PS 6984383-9.

$\rho=1.1133 \times 10^{-6} \mathrm{ohm}$ inch $*$

and that volume resistivity did not change significantly with exposure of the foil the $\mathrm{NaOH}$.

Then the foil thickness is

$\mathrm{t}=1.113 \times 10^{-5} / \mathrm{R}$ (meas).

The results of such data are displayed in Figures 5 and 6 . Analysis of the data is given in Appendix A.

A hypothesis was proposed that the etch rate should be constant with time. A computer program (Appendix B) was constructed using the resistance of pattern 04-01 starting at time $=0$ and using the resistance at time $=360$ seconds. The display of this hypothesis is plotted as line 5 of Figure 5 and line 6 of H'igure 6 .

\section{ACCOMPLISHMENTS}

'I'he experiment was successful in providing data to support the hypothesis that $\mathrm{NaOH}$ solutions could be used for surface preparation of specular finished aluminum foils. The data indicates that a 30 -second immersion in

* Charles D. Hodgman, Handbook of Chemistry and Physics, 35th Edition, Chemical Rubber Publishing Company. 


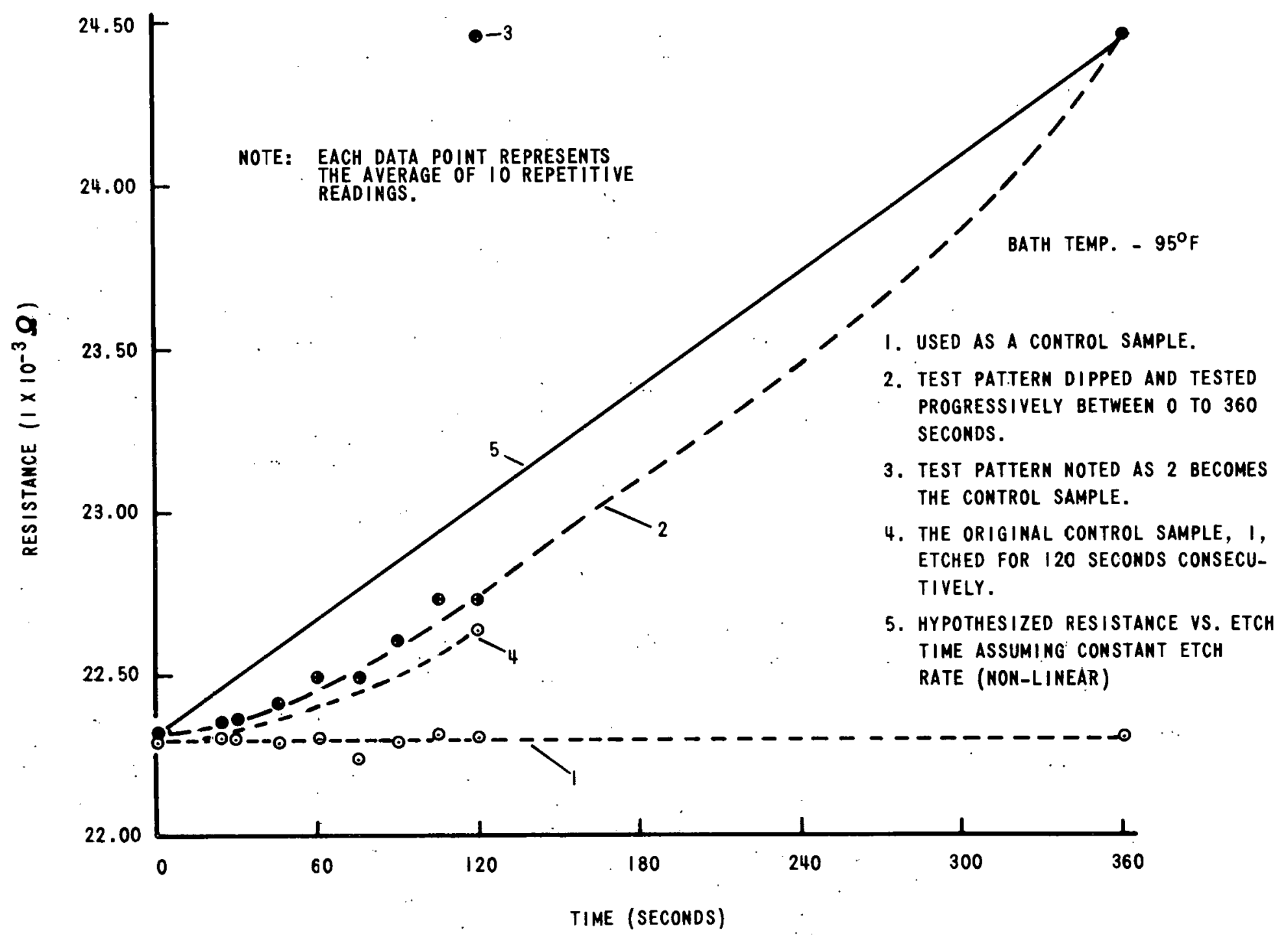

Figure 5. Resistance Versus Etch Time for Test Pattern Etched in 20 Grams per Liter NaOH Solution 


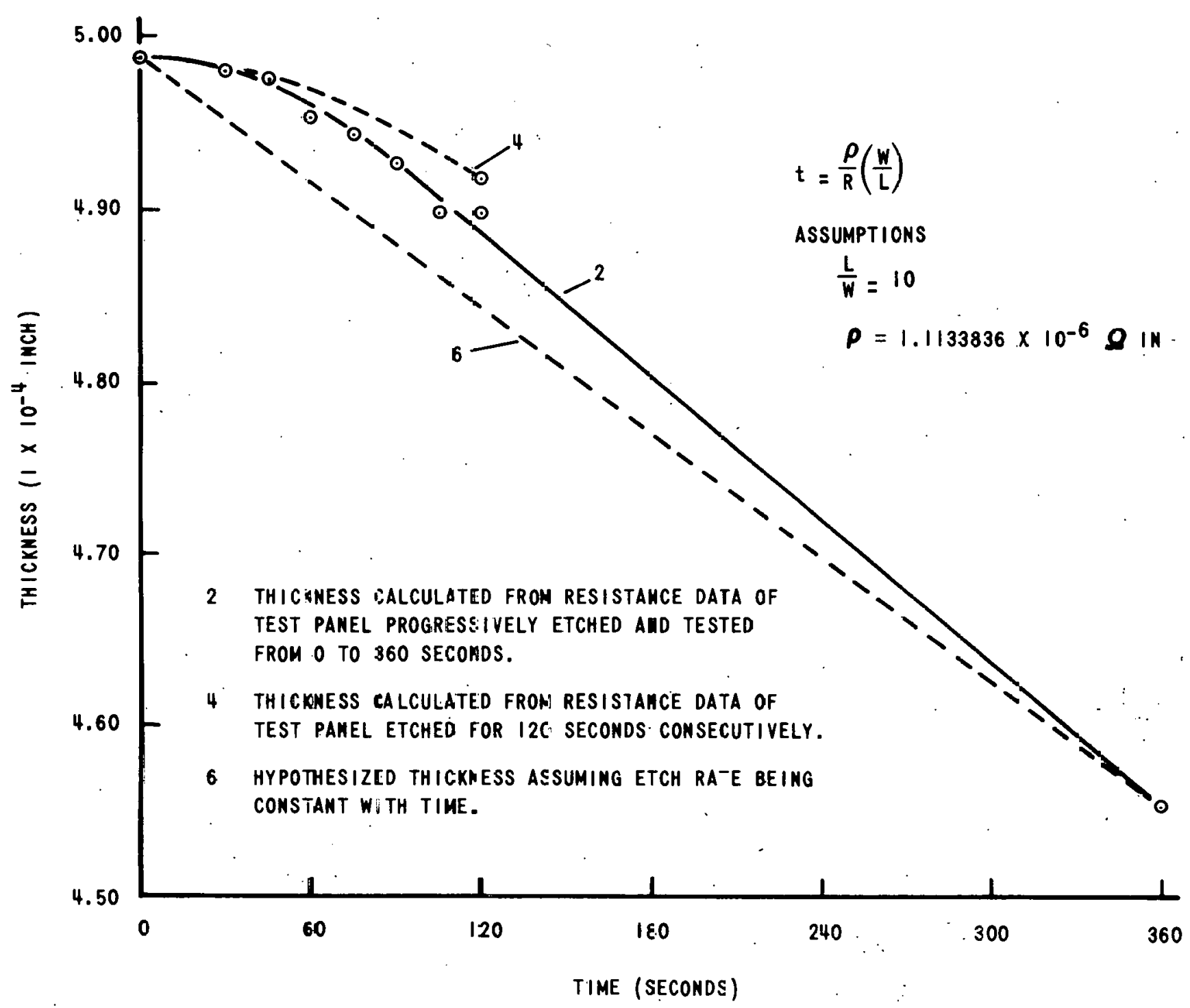

Figure 6. Calculated Thiskness Versus Etck Time of Test Pattern 
a. 20 gram per liter $\mathrm{NaOH}$ solution will reduce the thickness of a 0.00045 inch 1145-0 alloy aluminum foil by 0.8 percent. This decrease in thickness meets the requirement for present precision elements.

\section{FUTURE WORK}

The $\mathrm{NaOH}$ etch appears to prepare the surface such that present etching parameters are satisfied; however, photoresist adherence to specular aluminum surfaces and the mechanism causing the difference in etch time between specular and matte finish aluminum foils will be investigated.

Until results from these investigations are obtained, purchases under the existing specifications will be limited to material with matte surface of the foil exposed. 
Appendix A

DATA ANALYSIS FOR TEST PATTERN RESISTANCE VERSUS ETCH TIME 
THIS PAGE

\section{WAS INTENTIONALLY LEFT BLANK}


Table A-1. Analysis of Data for Resistance of Test Pattern Versus Etch Time in 20 Grams per Liter $\mathrm{NaOH}$ Solution

\begin{tabular}{|c|c|c|c|c|c|c|c|c|c|c|c|c|c|c|c|c|c|}
\hline \multirow[b]{2}{*}{ PATTERM } & \multirow{2}{*}{$\begin{array}{l}\text { TOTAL } \\
\text { ETCH } \\
\text { TIME } \\
\text { (SECONDS) }\end{array}$} & \multirow[b]{2}{*}{$N$} & \multirow[b]{2}{*}{$\begin{array}{l}\text { MEAM } \\
\left(10^{-5} \Omega\right)\end{array}$} & \multirow[b]{2}{*}{$\begin{array}{l}\text { SIGMA } \\
\left(10^{-6} \Omega\right)\end{array}$} & \multirow{2}{*}{$\begin{array}{l}\text { S|GMA / } \\
\text { MEAN } \\
\text { (PERCENT) }\end{array}$} & \multirow[b]{2}{*}{$\stackrel{\text { MIN }}{\left(10^{-5} \Omega\right)}$} & \multirow[b]{2}{*}{$\begin{array}{l}\operatorname{Max} \\
\left(10^{-5} \Omega\right)\end{array}$} & \multicolumn{10}{|c|}{ ORIGINAL DATA $\left(10^{-5} \Omega\right)^{\circ}$} \\
\hline & & & & & & & & 1 & 2 & 3 & 4 & 5 & 6 & 7 & 8 & 9 & 10 \\
\hline $04-1-1$ & 0 & 10 & 2232 & 8.433 & 0.04 & 2230 & 2232 & 2232 & 2232 & 2232 & 2232 & 2232 & 2232 & 2232 & 2232 & 2230 & 2230 \\
\hline $04-2-1$ & 0 & 10 & 2229 & 5.271 & 0.02 & 2229 & 2230 & 2230 & 2230 & 2230 & .2230 & 2230 & 2229 & 2229 & 2229 & 2229 & 2229 \\
\hline $04-1-2$ & 30 & 10 & 2237 & 0.000 & 0.00 & 2237 & 2237 & 2237 & 2237 & 2237 & 2237 & 2237 & 2237 & 2237 & 2237 & 2237 & 2237 \\
\hline $04-2-2$ & 0 & 10 & 2230 & 4.2 .17 & 0.02 & 2229 & 2230 & 2230 & 2230 & 2230 & 2230 & 2230 & 2230 & 2230 & 2230 & 2229 & 2229 \\
\hline $04-1-3$ & 45 & 10 & 2242 & 0.000 & 0.00 & 2242 & 2242 & 2242 & 2242 & 2242 & 2242 & 2242 & 2242 & 2242 & 2242 & 2242 & 2242 \\
\hline $04-2-3$ & 0 & 10 & 2228 & 12.52 & 0.06 & 2225 & 2229 & 2229 & 2229 & 2229 & 2225 & 2227 & 2227 & 2227 & 2228 & 2228 & 2228 \\
\hline $04-1-4$ & 60 & 10 & 2248 & 9.661 & 0.04 & 2246 & 2249 & 2249 & 2249 & 2249 & 2249 & 2249 & 2249 & 2246 & 2248 & 2248 & 2248 \\
\hline $04-2-4$ & 0 & 10 & 2230 & 4.832 & 0.02 & 2229 & 2230 & 2229 & 2230 & 2230 & 2230 & 2230 & 2230 & 2230 & 2230 & 2229 & 2229 \\
\hline $04-1-5$ & 75 & 10 & 2248 & 16.19 & 0.07 & 2245 & 2250 & 2250 & 2250 & 2245 & 2247 & 2247 & 2247 & 2249 & 2249 & 2249 & 2249 \\
\hline $04-2-5$ & 0 & 10 & 2223 & 6.667 & 0.03 & 2222 & 2224 & 2222 & 2223 & 2223 & 2223 & 2224 & 2222 & 2223 & 2223 & 2223 & 2223 \\
\hline $04-1-6$ & 90 & 10 & 2260 & 9.190 & 0.04 & 2259 & 2261 & 2261 & 2261 & 2261 & 2260 & 2260 & 2259 & 2259 & 2259 & 2259 & 2259 \\
\hline $04-2-6$ & 0 & 10 & 2229 & 0.000 & 0.00 & 2229 & 2229 & 2229 & 2229 & 2229 & 2229 & 2229 & 2229 & 2229 & 2229 & 2229 & 2229 \\
\hline $04-1-7$ & 105 & 10 & 2271 & 4.217 & 0.02 & 2270 & 2271 & 2271 & 2271 & 2271 & 2271 & 2271 & 2271 & 2271 & 2271 & 2270 & 2270 \\
\hline $04-2-7$ & 0 & 10 & 2231 & 3.163 & $.0 .0 !$ & 2230 & 2231 & 2230 & 2231. & 2231 & 2231 & 2231 & 2231 & 2231 & 2231 & 2231 & 2231 \\
\hline $04-1-8$ & 120 & 10 & 2273 & 0.000 & 0.00 & 2273 & 2273 & 2273 & 2273 & 2273 & 2273 & 2273 & 2273 & 2273 & 2273 & 2273 & 2273 \\
\hline $04-2-8$ & 0 & 10 & 2230 & 7.072 & 0.03 & 2229 & 2231 & 2229 & 2231 & 2231 & 2230 & 2230 & 2230 & 2231 & 2231 & 2231 & 2231 \\
\hline $04-1-9$ & 360 & 10 & 2446 & 0.000 & 0.00 & 2446 & 2446 & 2446 & 2446 & 2446 & 2446 & 2446 & 2446 & 2446 & 2446 & 2446 & 2446 \\
\hline $04-2-9$ & 0 & 10 & 2231 & 11.97 & 0.05 & 2229 & 2232 & 2229 & 2230 & 2230 & 2230 & 2230 & 2232 & 2232 & 2232 & 2232 & 2232 \\
\hline$* 04-1-10$ & 360 & 10 & 2446 & 9.661 & 0.04 & 2445 & 2447 & 2447 & 2447 & 2447 & 2447 & 2447 & 2447 & 2447 & 2445 & 2445 & 2445 \\
\hline${ }^{* *} 04-2-10$ & 120 & 10 & 2264 & 4.218 & 0.02 & 2263 & 2264 & 2263 & 2263 & 2264 & 2264 & 2264 & 2264 & 2264 & 2264 & 2264 & 2264 \\
\hline $\begin{array}{r}\text { * AT THIS } \\
\text { * AT THIS }\end{array}$ & $\begin{array}{l}\text { POINT 0.4-1 } \\
\text { POINT 0.4-2 }\end{array}$ & $\begin{array}{l}\text { BECAM } \\
\text { BECAM }\end{array}$ & E THE TEST & $\begin{array}{l}\text { OL SAMPLE } \\
\text { SAMPI.E }\end{array}$ & & & & . & & & & & & & & & \\
\hline
\end{tabular}


Appendix B

COMPUTER PROGRAM AND OUTPUT TO PREDICT THINNING OF ALUMINUM FOIL, ASSUMING CONSTANT ETCH RATE 
THIS PAGE

\section{WAS INTENTIONALLY \\ LEFT BLANK}




\section{PROGRAM (XTRAN)}

DIM ENSION $R(100), T(100), T M M(100)$, RNORM(100)

$\mathrm{RHO}=2.828 \mathrm{E}-8 * 39.37$

DISPLAY /, 'RHO = ', RHO, ' OHM IN.'

$\mathrm{RZRO}=2.232 \mathrm{E}-2$

$R(360)=2.446 \mathrm{E}-2$

$A L O W=10$.

$\mathrm{B}=\mathrm{RHO} * \mathrm{ALOW}$

$\mathrm{TZRO}=\mathrm{B} / \mathrm{RZRO}$

$A=(T Z R O / 360)-.(B /(360 . * R(360)))$

DISPLAY 'T(0) = ', TZRO, ' IN.'

DISPLAY 'B = ', B, ' OHM IN.'

DISPLAY 'A = ', A, ' IN. /SEC. '

DISPLAY /,'TIME THICKNESS

DO $100 \mathrm{I}=1,50$

IT $\Pi \mathrm{M}=10 * \mathrm{I}$

$T \Pi M(\mathrm{I})=\mathrm{FLOA} \mathrm{T}(\mathrm{ITIM})$

$\mathrm{T}(\mathrm{I})=\mathrm{T} Z \mathrm{RO}-\mathrm{A} * \mathrm{TIM}(\mathrm{I})$

$\mathrm{R}(\mathrm{I})=\mathrm{B} / \mathrm{T}(\mathrm{I})$

RNORM (I) $=\mathrm{TZRO} / \mathrm{T}(\mathrm{I})$

100 DISPLAY TIM(I), T(I), R(I), RNORM(I)

STOP

END

\section{OUTPUT}

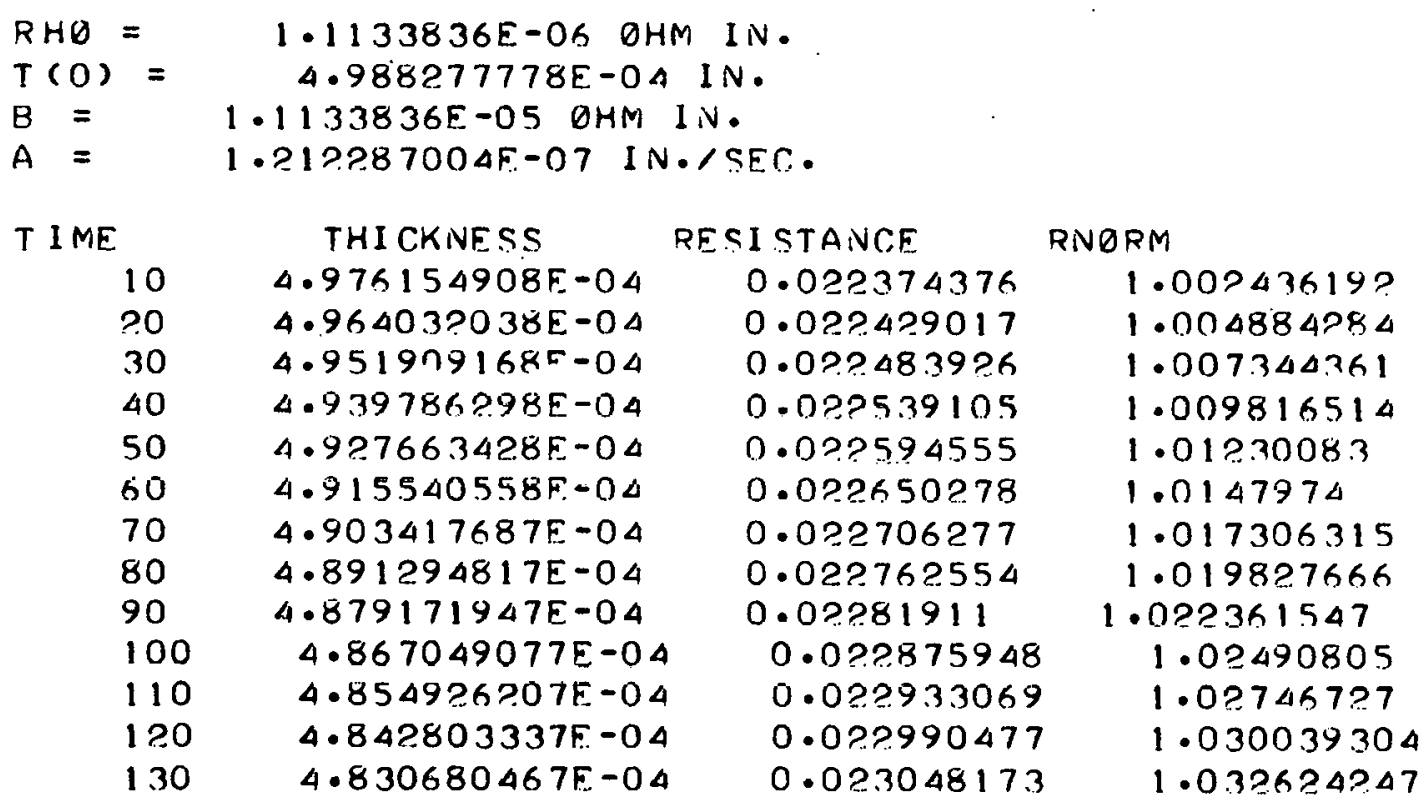




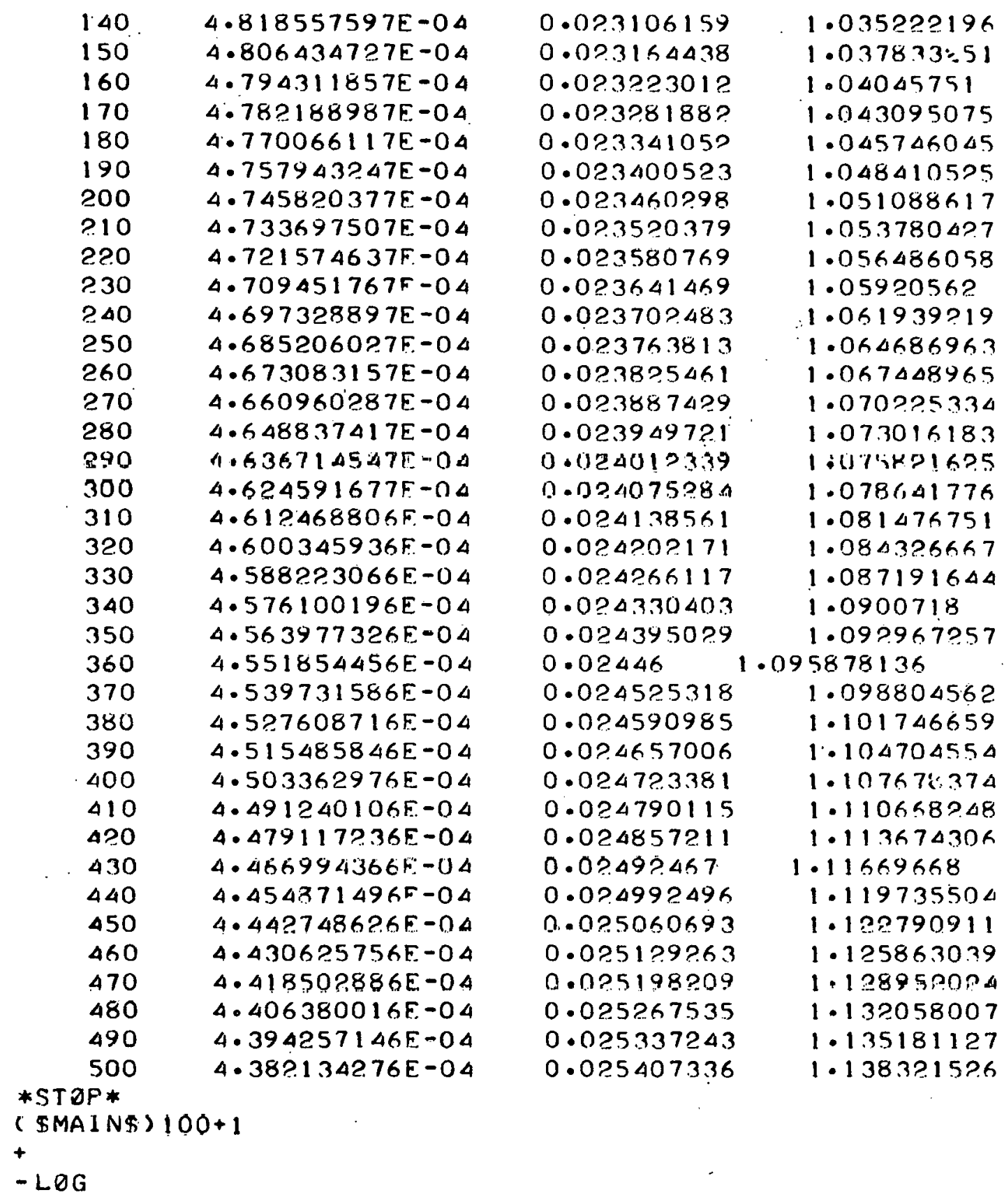

